\title{
ONLINE LEARNING IN SOCIAL ADAPTATION PERSPECTIVE
}

\author{
Pardamean Daulay ${ }^{1}$, M Chairul Basrun Umanailo ${ }^{2}$, Aulia Nursyifa ${ }^{3}$ \\ ${ }^{1}$ Department of Sociology, Faculty of Law, Social and Political Sciences, Universitas Terbuka, Banten, Indonesia \\ ${ }^{2}$ Faculty of Agriculture and Forestry, Iqra Buru University, Namlea, Indonesia \\ ${ }^{3}$ Department of Teacher Training and Education, Universitas Pamulang, Banten, Indonesia \\ e-mail: chairulbasrun@gmail.com (corresponding author)
}

\begin{tabular}{ll}
\hline \multicolumn{1}{c}{ Article Info } & Abstract \\
The trend of online learning is growing. The Circular of the Minister \\
of Education and Culture Numbers 2 and 3 of 2020 requires that the \\
adaptation; & entire teaching and learning process be carried out online. Not all \\
elements of society can accept online learning patterns as a medium \\
social \\
for transforming knowledge due to the availability of infrastructure to \\
the characteristics of the community itself. This study aims to explain \\
implementing online learning with the adaptation pattern proposed by \\
Robert Merton. The research design used is a literature review. \\
Articles are collected using the Science and Technology Index (Sinta) \\
link, Garba Reference Digital (Garuda), Ministry of Religious Affairs \\
Reference (Moraref), Indonesian Scientific Repository (Neliti) The \\
Preprint Server of Indonesia (RINarxiv). The time range used is 2011- \\
2021. Based on the results of the study and analysis of the articles \\
collected, it was found that the pattern of adaptation carried out by \\
educators and students is the antithesis of policies issued by the \\
government. The pattern of adaptation carried out by the community \\
is based on the resources and characteristics they have.
\end{tabular}

\begin{tabular}{ll}
\hline \multicolumn{1}{c}{ Article Info } & Abstrak \\
\hline & Tren pembelajaran online semakin berkembang, pemerintah melalui \\
Kata Kunci: & Surat Edaran Menteri Pendidikan dan Kebudayaan Nomor 2 dan 3 \\
Adaptasi; & tahun 2020 mensyaratkan untuk seluruh proses belajar mengajar \\
pola pembelajaran; & dilakukan secara online. Pada kenyataanya tidak semua elemen \\
sosial & masyarakat bisa menerima pola pembelajaran online sebagai media \\
& transformasi pengetahuan akibat dari ketersediaan infrastruktur \\
& hingga karakteristik masyarakat itu sendiri. Penelitian ini bertujuan \\
& menjelaskan situasi pelaksanaan pembelajaran online dengan pola \\
& adaptasi yang dikemukakan oleh Robert Merton. Desain penelitian \\
& yang digunakan adalah literature review, artikel dikumpulkan \\
& menggunakan tautan Science and Technology Index (Sinta), Garba \\
& Rujukan Digital (Garuda), Ministry of Religious Affairs Reference \\
& (Moraref), Repositori Ilmiah Indonesia (Neliti) The Preprint Server of \\
& Indonesia (RINarxiv). Rentang waktu yang digunakan tahun 2011- \\
& 2021. Berdasarkan hasil kajian serta analisis terhadap artikel yang \\
& dikumpulkan didapatkan bahwa pola adaptasi yang dilakukan oleh \\
& pendidik maupun peserta didik merupakan antitesis dari kebijakan \\
& yang dikeluarkan oleh pemerintah. Pola adaptasi yang dilakukan \\
& masyarakat berdasar pada sumber daya serta karakteristik yang \\
& mereka miliki. \\
\hline
\end{tabular}




\section{Introduction}

One of the Covid-19 pandemic impacts for the world of education is the delay in teaching and learning. All educational institutions, without exception, must carry out online learning (online). However, in reality, the infrastructure to support online learning is not yet fully and adequately available.

Figure 1. Internet Access (percent) per Household by Provinces 2018

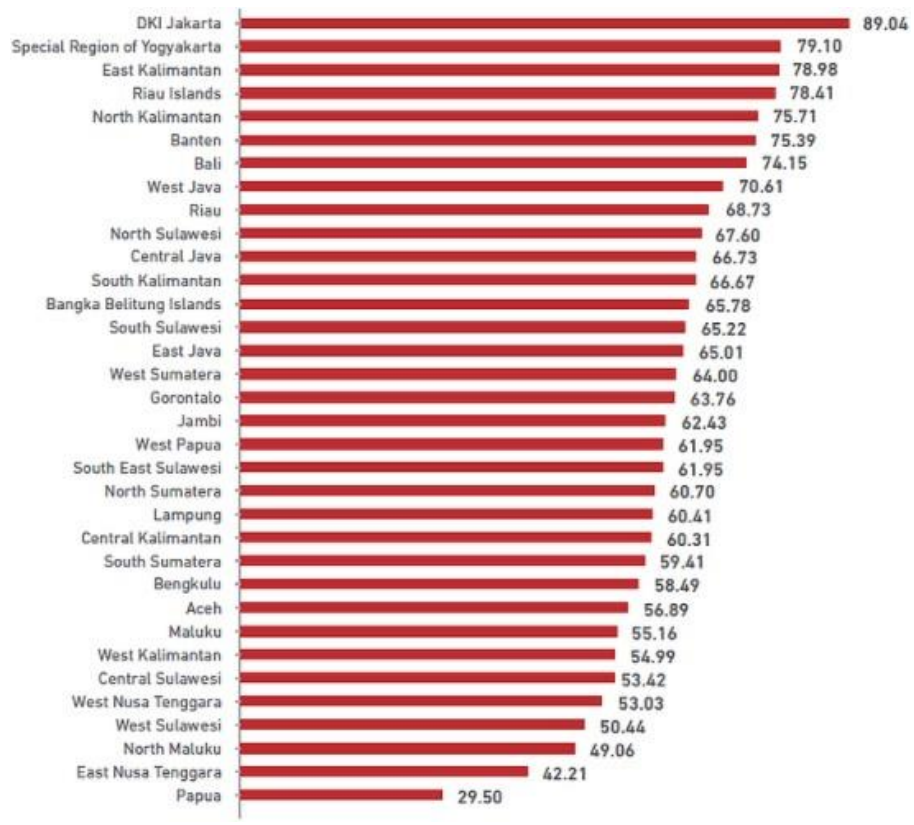

Source: Statistics Indonesia 2018

The policies taken by the government related to education during the pandemic are the Circular of the Minister of Education and Culture Number 2 of 2020, Number 3 of 2020, concerning online learning and working from home to prevent the spread of Covid-19, and the Circular Letter of the Minister of Education and Culture Number 4 In 2020, regarding the Implementation of Education Policies in the Emergency Period for the Spread of Coronavirus Disease (Covid-19) to carry out the learning process from home with the conditions required in the circular letter. This is a new challenge for the education system in Indonesia because it changes the old system into an online learning method (Widyangsih, 2020).

It should be noted that the unpreparedness of teachers and students towards online learning is also a problem. The move from conventional learning systems to online systems is considered quite sudden, without proper preparation. However, all of this must be carried out so that the learning process can run smoothly and students actively participate even in the conditions of the Covid-19 pandemic. Without realizing it, situations like this will give birth to deviant behavior for teachers and teaching participants.

In the study of adaptation and adjustment theory, Robert Merton considers anomie always to have positive consequences. However, it should be noted that one social factor can hurt other social facts. For example, in changing the learning process from conventional (face-to-face) to online learning in Indonesia, are students and educators able to adjust? Can the purpose of this change be implemented correctly and adequately? Of course, the policy change will affect students and educators in carrying out their learning activities.

As an alternative form of learning during the Covid-19 emergency, according to Moore, Dickson-Deane, \& Galyen (in Firman \& Rahayu, 2020), online learning is learning that uses the 
internet network with accessibility, connectivity, flexibility, and the ability to bring up various types of learning interactions but requires an enormous budgetin each implementation compared to the initial concept called identical teaching. With theactivity of delivering the subject matter in the classroom.

Based on these differences in interactions, learning activities can be carried out using various learning patterns. In particular, this learning pattern occurs because of a change in the teacher's role in learning activities. According to Barry Morris (in Riyana, 2015), learning patterns are grouped into 4 learning patterns (1). Learning pattern(traditional 1); (2). Learning pattern (traditional 2); (3). Teacher and Media are learning patterns; and (4). Media learning patterns. As shown in the following figure:

Figure 2. Learning Pattern



The selection of media learning patterns in the Covid-19 pandemic situation certainly has its impact on students. Several previous studies have shown a significant effect on students' adaptability to the implementation of online learning.

In his study of online learning during the Covid-19 pandemic, Firman, in his analysis of the availability of internet services and the cost implications for students, has difficulty studying the lecture materials given online. Lecture material, mainly reading material, cannot be understood thoroughly by students (Firman \& Rahayu, 2020). Anggi Nuryanti, in her research entitled student adaptation to the learning process as a form of mitigation effort during the Covid19 pandemic, conveyed the problem of difficulties in accessing the internet network, and there were still students who did not have basic computer skills (Nuryani et al., 2021). Likewise, an empirical study conducted by Herianda Dwi Putra Siregar revealed the problem of online learning in Indonesia related to the competency gap among teachers and lecturers who still stuttered about technology. Three previous studies show that the application of online learning during the Covid-19 pandemic still requires adjustment, or in sociological studies, it is mentioned as an adaptation to changes in society and institutions. This study reflects the phenomenon of the online learning model, which was analyzed analytically using the adaptation approach of Robert Merton to obtain a conceptual frame of reference regarding the sustainability of online learning in Indonesia.

\section{Methodology}

The method used in writing this article is a literature review with a systematic mapping study approach. Researchers conducted a literature search using the database Science and 
Technology Index (Sinta), Garba Rujukan Digital (Garuda), Ministry of Religious Affairs Reference (Moraref), Repositori Ilmiah Indonesia (Neliti) The Preprint Server of Indonesia (RINarxiv). At the initial stage of the search for journal articles obtained. At the scene of searching for journal articles with the online keyword learning,various amounts were obtained from each source, as shown in the following table:

Table 1. Reference Sources With Online Learning Keywords

\begin{tabular}{|l|l|c|c|}
\hline \multicolumn{1}{|c|}{ Source } & \multicolumn{1}{c|}{ Keywords } & Time Range & Result \\
\hline https://garuda.ristekbrin.go.id & Pembelajaran online & $2020-2021$ & 237 \\
\hline https://sinta.ristekbrin.go.id/journals & Pembelajaran & $2020-2021$ & 85 \\
\hline https://rama.ristekbrin.go.id & Pembelajaran online & - & 35 \\
\hline https://moraref.kemenag.go.id & Pembelajaran online & $2020-2021$ & 30 \\
\hline https://rinarxiv.lipi.go.id & Pembelajaran online & - & 1 \\
\hline https://www.neliti.com & Pembelajaran online & $2020-2021$ & 54 \\
\hline
\end{tabular}

Source: Data Compilation 2021

Table 2. Reference Sources with the keyword social adaptation

\begin{tabular}{|l|l|c|c|}
\hline \multicolumn{1}{|c|}{ Sumber } & \multicolumn{1}{c|}{ Keywords } & Time Range & Result \\
\hline https://garuda.ristekbrin.go.id & Adaptasi Sosial & $2011-2021$ & 83 \\
\hline https://sinta.ristekbrin.go.id/journals & Sosial & $2020-2021$ & 146 \\
\hline https://rama.ristekbrin.go.id & Adaptasi Sosial & - & 49 \\
\hline https://moraref.kemenag.go.id & Adaptasi Sosial & $2012-2019$ & 9 \\
\hline https://rinarxiv.lipi.go.id & Sosial & - & 1 \\
\hline https://www.neliti.com & Adaptasi Sosial & $2011-2021$ & 123 \\
\hline
\end{tabular}

Source: Data Compilation 2021

The journals and articles found are then explored to find relevance to the research theme. From 442 for online learning keywords and 411 for social adaptation keywords, the authors chose 91 articles that have criteria tied to online learning and social adaptation concepts. In the last stage, the writer chose 12 articles that met the full criteria, 7 had medium criteria, and 2 had low criteria.

\section{Discussions}

The adaptation process is one part of cultural evolution, namely a process that includes a series of human efforts to adapt or respond to changes in the physical and social environment that occur temporarily. Environmental changes that are very influential on human adaptation are environmental changes in the form of disasters, namely events that threaten the survival of organisms, including humans.

Changes in learning patterns that must be carried out during a pandemic certainly require their adaptation pattern. Robert Merton proposed five patterns of adaptation, indicating that there is a form of adaptation to certain situations in deviant behavior. Deviant behavior can occur because there is no link between goals and ways that have been set and justified in the social structure (Wulandari, 2019). The position of online learning can be seen in anomie, which is also caused by the disharmony between cultural goals and formal ways to achieve these goals (Priyanto, 2018). The theory put forward by Merton can be an analytical tool to show the phenomenon of adaptation by society to online learning today.

Online learning can be done by having a PC, Smartphone, or Laptop with certain specifications. Likewise, the internet network and accessibility to learning service provider applications such as Zoom, Webex, Google Classroom. Meanwhile, the affordability of the internet in Indonesia has not touched all regions in Indonesia, especially the 3T areas (frontier, remote and underdeveloped). Data from the Ministry of Communication and Information for 
2020 released 20,341 3T categories and 9,113 villages, which had not been accessed by 4G (Basid \& Saimroh, 2020). In addition, data from the Association of Indonesian Internet Service Providers (APJI1) states that the number of internet users in Indonesia is 143.26 million, or approximately 55\% of the population. This means that there are still $45 \%$ remaining, approximately 117 million people still untouched by the internet (Henri Kasyfi Soemartono, 2018).

In the next situation, the impact of the pandemic is felt by people in the lower middleclass with limited income during the pandemic. It is not easy to open up opportunities to buy PCs, Smartphones, or Laptops for online learning devices. In 2020 the World Bank released research results related to financial impacts related to students as described below:

Figure 3. Dampak pada rata-rata penghasilan tahunan per siswa

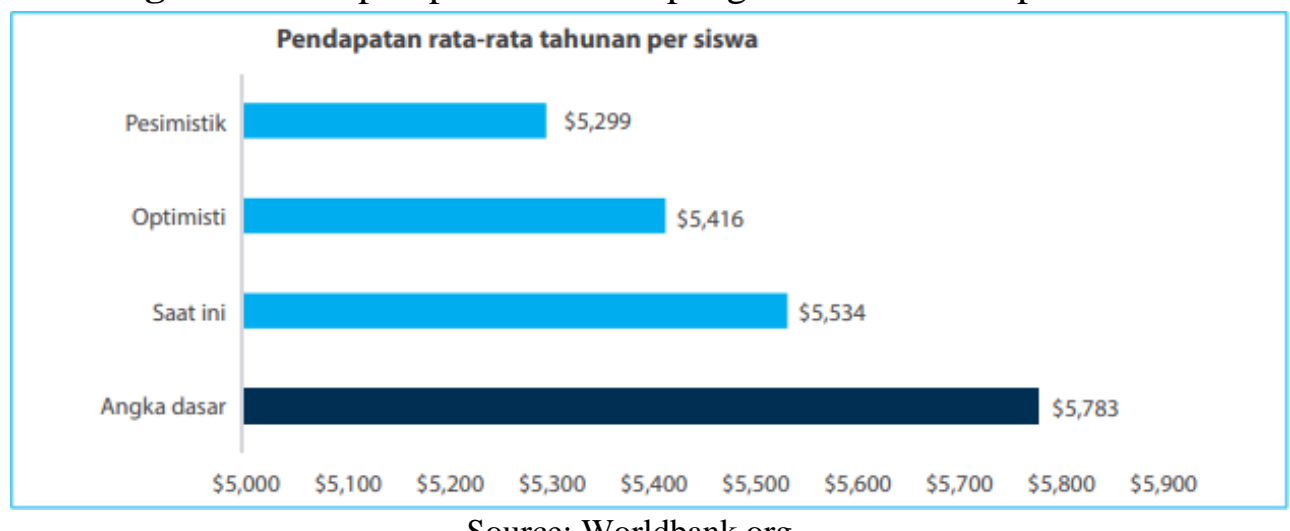

Source: Worldbank.org

The World Bank data in Figure 3 shows that 18 percent of the households observed had family members who stopped working or experienced a decrease in working hours to provide learning assistance to children due to school closures. For these households, this burden is most often borne by the mother ( 66 percent) and the father ( 42 percent) or other family members. There is pressure from parents in Indonesia and around the world to reopen schools (Yarrow, Masood, \& Afkar, 2020).

Online learning needs the support of resources, the resources intended in this study are in the form of organizers and curriculum. Schools and universities in general act as organizers. All actions are organized in one policy direction regulated by the government through the Circular Letter of the Minister of Education and Culture Number 2 of 2020 concerning online learning (Humas, 2020). Furthermore, through a Joint Decree of the Minister of Education and Culture, the Minister of Religion, the Minister of Health, and the Minister of Home Affairs of the Republic of Indonesia concerning Guidelines for the Implementation of Learning in the 2020/2021 Academic Year and the 2020/2021 Academic Year during the 2019 Coronavirus Disease Pandemic (Covid-19) (Kemendikbud, 2020), adding to the anxiety of education providers with the birth of the Emergency Curriculum (under Special Conditions) which is considered an emergency curriculum, simplification of basic competencies which refers to the 2013 curriculum. Sociologically, this policy has become a new phenomenon for most schools and colleges organizing the learning process with a face-to-face (offline) pattern. What are the consequences? Not a few schools and colleges are feverish with online learning policies. The implication is on students' learning process or increasingly chaoticstudents and has no clear orientation.

As a result of the implementation of online learning starting from March 2020, students and students independently must actively follow information updates regarding which platforms and courses they will carry out online learning, giving assignments and quizzes, and providing the material (Putri, 2020). This learning technique fully adapts to the policies of teachers and 
lecturers in each lesson. Platforms that can be used include: google classroom (Achmad Imam, 2020), video conference (Fattah \& Azis, 2020), live chat, zoom (Haqien \& Rahman, 2020), Webex, and WhatsApp group (Trisnani, 2017). The problem that often arises is adjusting teaching styles, learning, and media resources that are difficult for certain circles. The implication is that the learning processis increasingly undirected and even impressed "yang penting online"

The next problem is "Capital." Online learning does not necessarily provide convenience in every use. Through its internet quota subsidy policy, the government hasnot fully touched the community in certain segments. The problem is, not all students or students have the devices mentioned earlier. In the end, the internet quota provided cannot be utilized optimally. Another capital that is no less important is the culture and character of educators and students in the online learning process, which is often a big obstacle to achieving the ultimate goal.

Merton suggests a typology of adapting to situations, namely conformity, innovation, ritualism, isolation, and rebellion (the last four are deviant behavior).

Carrying out online learning regardless of the risks, impacts, and consequences for society is a form of conformity. Conformity itself can be interpreted as a condition in which citizens continue to accept the goals and means of society because of moral pressure (Rospita \& Agung, 2020). Schools and universities are an inseparable part of government influence. Policies and other institutions issued by the government have their own coercive power. Although all educational institutions must follow the policy, as the author has stated before, the learning process has stalled, learning output has not been achieved. However, the community still accepts the application of online learning as a new learning instrument. Even to the point of protesting, many parents who then struggled finally accepted the online learning pattern as an instrument in the educational process. The substance of the condition of conformity to the implementation of online learning is that people must continue to accept the goals and means contained in the implementation, even though there are limitations such as the ability to have tools or infrastructure for online learning, the ability to access resources such as knowledge in operationalizing applications and community empowerment in fulfilment of infrastructure functions such as data packages and Wifi (Qadafi, 2020). This condition has not been added to the geographical presence and difficult environmental limitations that are not even availablefor them, such as signals or internet networks. On the institutional side, schools and universities will be in a conformity situation even though they are only given limited time to familiarize hardware and software devices with online learning policies due to moral pressure.

Not all people can accept online learning as desired by the government. The innovations in Merton's typology of adaptation convey situations where the goals that exist in society are recognized and maintained, but they change the means used to achieve these goals. Implementing online learning in the typology of innovation, the actions that can be understood are limitations that are changed in new ways or patterns.

Learning is carried out through a computer device (PC) or laptop connected to an internet network connection. Teachers conduct learning together at the same time using groups on social media such as Whatsapp (WA), telegram, Zoom application or other social media as a learning tool to ensure students study at the same time even though in different places, even though the curriculum has determined software standards and learning applications (Strategi Resiliensi Paud Alam Al Firdaus Di Masa Covid 19," 2020). Many teachers then include learning videos via YouTube to follow online, but thispattern is not included in the online learning category as stipulated in the rules.

Originally, a study was conducted in an appropriate and accommodating room, but during the Covid-19 pandemic, the study room was considered wide and everywhere. The phenomenon of educators or students doing online learning partially indicates that society is in a pattern of ritualism (Wulandari, Anggraini, Care, \& Ipb, 2020). Ritualism is defined as a situation in which citizens reject the goals that have been set and choose the means that have been determined. The 
purpose of online learning indicates a transformation of knowledge with online media and learning patterns adapted to the curriculum. Still, for students and educators joining online networks and being present in communication spaces, it is sufficient without having to be followed by predetermined learning standards.

In its development, many parents of students refuse to do online learning for children's educational goals. This refusal was done by calling a private teacher to teach at home (Jatmika, 2020). In general, they do not accept online learning as a substitute method for conventional learning that has been done so far. In Merton's adaptation pattern, this condition is referred to as self-isolation, where the community members reject the goals and means that are already available in society.

The next condition in Merton's study is that rebellion is a form of adaptation, namely a situation where the goals and means contained in society are rejected and try to replace or change them entirely. Examples that can be raised are from the educators' side, especially those approaching retirement age and teachers in 3T areas (front, remote and underdeveloped). Online learning is very difficult to implement. This is because most teachers are weak with mastery of information technology (IT) in online learning (Asmuni, 2020; Aminullah et al., 2021); inadequate supporting facilities and infrastructure in online learning (Wulandari, et al., 2020); Another weakness lies in the not yet optimal competence of teachers related to literacy mastery competence, class management skills competence and communication and social competence (Sudrajat, 2020). Therefore, teachers cannot adapt to optimize the online learning process with all its limitations and inaccessibility. Therefore, cooperation is needed from the government, schools, teachers, communities, and even parents to jointly support education transformation during the COVID-19 pandemic.

\section{Conclusions}

Online learning is one of the approaches taken to transform education during the COVID19 pandemic. Still, online learning has also become a new atmosphere for most Indonesians, so Merton, in the adaptation approach, proposes five patterns that are put forward as conformity, innovation, ritualism, rejection, and rebellion. Each of the proposed patterns can be found in social life, a reality where individuals and groups seek to show an attitude of agreeing or disagreeing with a policy. Although the public can well receive not all things in online learning during the pandemic, calculations about economic conditions, resources, and psychology must be a reference for the government in supporting the transformation of education during the COVID19 pandemic in Indonesia.

\section{Acknowledgments}

The author would like to thank: Center for Overseas Student Management- Institute for Education Quality Assurance and Development LPPM Open University for the support and cooperation in preparing the article. Center for Planning and Community Development, University of Iqra Buru, and Institute for Research and Community Service at Pamulang University for their research collaboration.

\section{References}

Achmad Imam, T. R. H. S. E. I. (2020). Media E-learning Berbasis Google Classroom Untuk Meningkatkan Hasil Belajar Siswa SMK. Jurnal Pendidikan Teknik Elektro, 9(3), 6056010 .

Aminullah, Ikram, Chandra, F., Fitriani, N., Wasna, Misna, \& Elihami. (2021). Proses Pembelajaran Selama Masa Pandemi Covid 19 (Studi Pelaksanaan PLP Dasar). Maspul 
Journal of Community Empowerment, 3(1), 21-26. Retrieved from https://ummaspul.ejournal.id/pengabdian/article/view/1307

Asmuni. (2020). Problematika Pembelajaran Daring di Masa Pandemi Covid 19 dan Solusi Pemecahannya. Jurnal Paedagogy, 7(4), 281-288. https://doi.org/https://doi.org/10.33394/jp.v7i4.2941

Basid, A., \& Saimroh. (2020). Kesiapan Pesantren Di Era Kenormalan Baru. In Pembelajaran Jarak Jauh Era Covid-19.

Fattah, F., \& Azis, H. (2020). Pemanfaatan Video Conference Pada Yayasan Sinergi Cendikia Makassar. Ilkomas, 1(2), 18-23.

Firman, F., \& Rahayu, S. (2020). Pembelajaran Online di Tengah Pandemi Covid-19. Indonesian Journal of Educational Science (IJES), 2(2), 81-89.https://doi.org/10.31605/ijes.v2i2.659

Haqien, D., \& Rahman, A. A. (2020). Pemanfaatan Zoom Meeting untuk Proses Pembelajaran pada Masa Pandemi Covid-19. SAP (Susunan Artikel Pendidikan), 5(1). https://doi.org/10.30998/sap.v5i1.6511

Henri Kasyfi Soemartono. (2018). Survei APJII: Penetrasi Internet di Indonesia Capai 143 Juta Jiwa. Buletin Asosiasi Penyelenggara Jasa Internet Indonesia, Edisi-222, 3.

Humas. (2020). Sekretariat Kabinet Republik Indonesia | Inilah Perubahan Kebijakan Pendidikan Selama Masa Pandemi Covid-19- Sekretariat Kabinet Republik Indonesia. Https://Setkab.Go.Id/.

Jatmika, D. (2020). Webinar Growth-Mindset untuk Pembelajaran Online Pada Siswa SMA di Samarinda. Altruis: Journal of Community Services, 1(4), 188. https://doi.org/10.22219/altruis.v1i4.14669

Kemendikbud. (2020). Panduan Penyelenggaraan Pembelajaran Pada Tahun Ajaran 2020/2021 dan Tahun Akademik 2020/2021 di Masa Pandemi Corona virus Disease 2019 (COVID19) Keputusan Bersama 4 Menteri. In Kemendikbud (Vol.2019).

Nuryani, A., Prasetyawati, I., Zakki, A. M., Satiti, E. M., Risnanti, F., Lestatri, E. W., \&Hafida, S. H. N. (2021). Adaptasi Siswa Terhadap Proses Pembelajaran Sebagai Bentuk Upaya Mitigasi Selama Pandemi Covid-19. Jurnal Elementary: Kajian Teori Dan Hasil Penelitian Pendidikan Sekolah Dasar, 4(1), 60-65.

Priyanto, L. D. (2018). The Relationship of Age, Educational Background, and Physical Activity on Female Students with Anemia. Jurnal Berkala Epidemiologi, 6(2), 139. https://doi.org/10.20473/jbe.v6i22018.139-146

Putri, C. O. Y. (2020). Pembelajaran Daring, Efektif Gak Sih Buat Mahasiswa?

Qadafi, M. (2020). Pembelajaran Bahasa Inggris pada Anak di Sangkhom Islam Wittaya School saat Pandemi Covid-19. Jurnal Obsesi : Jurnal Pendidikan Anak Usia Dini, 5(1), 422. https://doi.org/10.31004/obsesi.v5i1.591

Riyana, C. (2015). Produksi Bahan Pembelajaran Berbasis Online. Modul Pembelajaran Universitas Terbuka Tangerang Selatan, 1-43.

Rospita, M., \& Agung, I. M. (2020). Identitas Sosial dan Konformitas Pada Anggota Komunitas Hijabers. Marwah: Jurnal Perempuan, Agama Dan Jender, 18(2), 187. https://doi.org/10.24014/marwah.v18i2.6968

Strategi Resiliensi Paud Alam Al Firdaus di Masa Covid 19. (2020). Jurnal Resolusi Konflik, CSR Dan Pemberdayaan (CARE), 5(1), 52-62.

Sudrajat, J. (2020). Kompetensi Guru Di Masa Pandemi Covid 19. Jurnal Ekonomi Dan Bisnis, 13(1), 100-110. https://doi.org/http://dx.doi.org/10.26623/jreb.v13i2.2434

Trisnani. (2017). Pemanfaatan Whatsapp Sebagai Media Komunikasi Dan Kepuasan Dalam Penyampaian Pesan Dikalangan Tokoh Masyarakat. Jurnal Komunika: Jurnal Komunikasi, Media Dan Informatika, 6(3). https://doi.org/10.31504/komunika.v6i3.1227 
Widyangsih, O. (2020). Penerapan Pembelajaran Online (Dalam Jaringan) Di Sekolah Dasar. Trapsila: Jurnal Pendidikan Dasar, 2(02), 50. https://doi.org/10.30742/tpd.v2i2.1106

Wulandari, M. A., Arga, H. S. P., Kelana, J. B., Altaftazani, D. H., \& Ruqoyyah, S. (2020). Analisis Pembelajaran Daring Pada Guru Sekolah Dasar di Era Covid 19.Jurnal Ilmiah $\begin{array}{lllll}\text { UPT } & P 2 M & \text { STKIP } & \text { SIliwangi, } & 7(2),\end{array}$ https://doi.org/https://doi.org/10.22460/p2m.v7i2p\%25p.2002

Wulandari, S. (2019). Adaptasi Perempuan Terpidana Membunuh. JOM FISIP, 6, 1-14.

Wulandari, Y. P., Anggraini, L. B., Care, P., \& Ipb, L. (2020). Strategi Resiliensi Paud Alam Al Firdaus Di Masa Covid 19 ( Resilience Strategy of PAUD Alam Al Firdaus in The Pandemic Covid-19 ). Jurnal CARE, 5(September).

Yarrow, N., Masood, E., \& Afkar, R. (2020). Estimasi Dampak COVID-19 pada Sistem Pembelajaran dan Pendapatan di Indonesia. 